\title{
KUALITAS PELAYANAN PUBLIK PEMERINTAH DAERAH (Kasus Pelayanan IMB pada KPTSA Kabupaten Bone)
}

\author{
RabinaYunus \\ Fakultas Ilmu Sosial dan Ilmu Politik Universitas Universitas Hasanuddin \\ Jl. P. Kemerdekaan Km. 10 Tamalarea Makassar, Kampus Unhas Tamalanrea Makassar, \\ Telp. (0411) 585024, 586200 (ext. 2211, 2100)
}

\begin{abstract}
Measuring the quality of public services in the Building Permit in the one-stop services office of Bone Regency, using indicators of the ability of the apparatus, system services and influential factor in the service of Building permit. The data was collected through interviews, observation and documentation, as a way to know the description of the organizational structure, education and training, ability to work completion on schedule, the convenience in obtaining services, clarity of information, security and protection services to consumers in the Office of One-Stop Services (KPTSA) of Bone Regency. The factors that affect the public service of Building Permit (IMB), among others; timeliness, ease of filing, the accuracy of service, the cost of service. Factor is a barometer of the consumer or the use of the service, so whether or not the services provided by the government back to the things mentioned above. In the public service should further develop the quality of human resources and democratization, leadership model must shift from power to the approach of expertise (from macho to maestro) and democratic in spirit, close to the subordinates and apply humanistic model of bureaucracy is putting a human in its proportions.
\end{abstract}

Keywords: Quality, One-Stop Services, Local Government

\section{ABSTRAK}

Mengukur kualitas pelayanan publik dalam Izin Bangunan di kantor pelayanan satu atap Kabupaten Bone, dengan menggunakan indikator kemampuan aparatur, sistem layanan dan faktor yang berpengaruh dalam pelayanan Membangun izin. Data dikumpulkan melalui wawancara, observasi dan dokumentasi, sebagai cara untuk mengetahui gambaran struktur organisasi, pendidikan dan pelatihan, kemampuan untuk bekerja selesai sesuai jadwal, kenyamanan dalam memperoleh pelayanan, kejelasan layanan informasi, keamanan dan perlindungan kepada konsumen di Kantor Pelayanan Satu Atap (KPTSA) Kabupaten Bone. Faktorfaktor yang mempengaruhi pelayanan publik Izin Mendirikan Bangunan (IMB), antara lain; ketepatan waktu, kemudahan pengajuan, akurasi pelayanan, biaya pelayanan. Faktor adalah barometer konsumen atau penggunaan layanan, sehingga apakah layanan yang diberikan oleh pemerintah kembali ke hal-hal tersebut di atas. Dalam layanan publik lebih lanjut harus mengembangkan kualitas sumber daya manusia dan demokratisasi, model kepemimpinan harus bergeser dari kekuasaan ke pendekatan keahlian (dari macho untuk maestro) dan berjiwa demokratis, dekat dengan bawahan dan menerapkan model birokrasi humanistik adalah meletakkan manusia dalam proporsinya.

Kata kunci: Kualitas, Pelayanan Satu Atap, Pemerintah Daerah 


\section{A. LATAR BELAKANG}

Pelayanan merupakan tugas utama yang hakiki dari sosok aparatur, sebagai abdi negara dan abdi masyarakat. Tugas ini telah jelas digariskan dalam pembukaan UUD 1945 alinea keempat, yang meliputi 4 (empat) aspek pelayanan pokok aparatur terhadap masyarakat, yaitu melindungi segenap bangsa Indonesia dan seluruh tumpah darah Indonesia, memajukan kesejahteraan umum, mencerdaskan kehidupan bangsa dan melaksanakan ketertiban dunia yang berdasarkan kemerdekaan, perdamaian abadi dan keadilan sosial.

Salah satu komitmen dalam pembentukan pemerintahan adalah kerelaan warga negara untuk taat kepada aturan-aturan hukum, kesediaan untuk mendukung setiap kebijakan yang ditetapkan oleh pemerintah, sedangkan pemerintah berkewajiban memberikan perlindungan dan kesejahteraan kepada masyarakat. Dalam pelaksanaan komitmen itu kemudian timbul suatu jalinan hubungan yaitu hubungan pemerintahan. Hubungan ini terjadi antara Pemerintah dan yang diperintah atau masyarakat bahwa masing-masing pihak mempunyai posisi dan peran tertentu. Pemerintah berperan sebagai penyedia pelayanan kebutuhan bagi masyarakat, sedangkan masyarakat berperan sebagai penerima pelayanan dari pemerintah.

Tugas pemerintah pada hakekatnya adalah mengatur dan melayani masyarakat dengan sebaik-baiknya. Komitmen ini hanya bisa dipegang kalau rakyat merasa bahwa pemerintahan yang berjalan masih mengarah pada upaya untuk melindungi dan melayani masyarakat. Tugas pelayanan umum (public service) kepada masyarakat lebih menekankan kepada mendahulukan kepentingan masyarakat, mempermudah urusan masyarakat, mempersingkat waktu proses pelaksanaan urusan masyarakat dan memberikan kepuasan kepada masyarakat.

Lahirnya UU No. 25 Tahun 2009 tentang Pelayanan Publik merupakan tantangan tersendiri dalam peningkatan kualitas pelayanan publik, terutama bagi organisasi pemerintah daerah dalam meningkatkan kepuasan masyarakat sebagai pelanggan layanan publik.
Salah satu jenis pelayanan publik yang diberikan oleh Pemerintah Kabupaten Bone yang banyak mendapat keluhan dari masyarakat adalah pelayanan bidang IMB (Izin Mendirikan Bangunan).

Mengingat pentingnya kebutuhan akan fasilitas perumahan yang menjadi salah satu kebutuhan pokok dari masyarakat, dimana untuk membangun fasilitas perumahan tersebut dibutuhkan adanya suatu izin pendirian. Namun dalam proses mendapatkan IMB tersebut, masyarakat sering mengeluhkan pelayanan IMB oleh Kantor Pelayanan Terpadu Satu Atap (KPTSA), diantaranya adalah masih adanya penyimpangan baik dari segi prosedur, biaya maupun waktu penyelesaiannya. Berbagai keluhan masyarakat terhadap pelayanan IMB yang diberikan oleh Kantor Pelayanan Terpadu Satu Atap secara implisit menunjukkan bahwa kualitas pelayanan publik khususnya bidang IMB tersebut masih rendah.

Pemerintah sebagai pemegang otoritas urusan pelayanan publik tampaknya lupa diri yang kemudian melakukan berbagai penyimpangan. Masyarakat sebagai pihak yang harus mendapatkan pelayanan dari pemerintah, yang secara langsung dapat merasakan manfaatnya sekaligus yang menanggung konsekuensi buruk dari pelayanan, karena itu diperlukan sikap proaktif masyarakat dalam melakukan pengawasan masyarakat terhadap aktivitas pemerintah dalam memberikan pelayanan kepada masyarakat.

\section{B. RUMUSAN MASALAH}

Berdasarkan uraian latar belakang, maka masalah penelitian ini dapat dirumuskan sebagai berikut :

1) Bagaimana kualitas pelayanan publik bidang IMB pada Kantor Pelayanan Terpadu Satu Atap (KPTSA) Di Kabupaten Bone?

2) Bagaimana sistem pelayanan IMB pada Kantor Pelayanan Terpadu Satu Atap (KPTSA) Di Kabupaten Bone?

3) Faktor-faktor apakah yang mempengaruhi kualitas pelayanan publik bidang IMB pada Kantor Pelayanan Terpadu Satu Atap (KPTSA) Di Kab. Bone?. 


\section{TUJUAN PENELITIAN}

Tujuan penelitian ini dapat dirumuskan yaitu :

1. Menganalisis aspek yang menentukan kualitas pelayanan publik bidang IMB di Kantor Pelayanan Terpadu Satu Atap (KPTSA) Di Kabupaten Bone dilihat dari aspek struktur organisasi, kemampuan aparat, dan sistem pelayanan.

2. Menganalisis sistem pelayanan IMB pada Kantor Pelayanan Terpadu Satu Atap (KPTSA) Di Kabupaten Bone.

3. Mengidentifikasi faktor-faktor yang mempengaruhi kualitas pelayanan bidang IMB di Kantor Pelayanan Terpadu Satu Atap (KPTSA) Di Kabupaten Bone seperti Ketepatan waktu, kemudahan dalam pengajuan, akurasi pelayanan bebas dari kesalahan dan biaya pelayanan.

\section{KONSEP PELAYANAN PUBLIK}

Pelayanan publik dapat diartikan sebagai pemberian pelayanan (melayani) keperluan orang atau masyarakat yang mempunyai kepentingan pada organisasi itu sesuai dengan aturan pokok dan tata cara yang telah ditetapkan. Sebagaimana telah dikemukakan terdahulu bahwa pemerintahan pada hakekatnya adalah pelayanan kepada masyarakat. Ia tidaklah diadakan untuk melayani dirinya sendiri, tetapi untuk melayani masyarakat serta menciptakan kondisi yang memungkinkan setiap anggota masyarakat mengembangkan kemampuan dan kreativitasnya demi mencapai tujuan bersama (Rasyid, 1998). Karenanya birokrasi publik berkewajiban dan bertanggung jawab untuk memberikan pelayanan baik dan profesional.

Pelayanan publik (public services) oleh birokrasi publik tadi adalah merupakan salah satu perwujudan dari fungsi aparatur negara sebagai abdi masyarakat di samping sebagai abdi negara. Pelayanan publik (public services) oleh birokrasi publik dimaksudkan untuk mensejahterakan masyarakat (warga negara) dari suatu negara kesejahteraan (welfare state).
Pelayanan umum oleh Lembaga Administrasi Negara (1998) diartikan sebagai segala bentuk kegiatan pelayanan umum yang dilaksanakan oleh Instansi Pemerintah di Pusat, di Daerah dan di lingkungan Badan Usaha Milik Negara/Daerah dalam bentuk barang dan atau jasa baik dalam rangka upaya kebutuhan masyarakat maupun dalam rangka pelaksanaan ketentuan peraturan perundang-undangan.

Ukuran/standar pelayanan publik yang profesional, yang artinya pelayanan publik dicirikan oleh adanya akuntabilitas dan responsibilitas dari pemberi pelayanan (aparatur pemerintah). Dengan ciri sebagai berikut:

1. Efektif, lebih mengutamakan pada pencapaian apa yang menjadi tujuan dan sasaran;

2. Sederhana, mengandung arti prosedur/ tata cara pelayanan diselenggarakan secara mudah, cepat, tepat, tidak berbelitbelit, mudah dipahami dan mudah dilaksanakan oleh masyarakat yang meminta pelayanan;

3. Kejelasan dan kepastian (transparan), mengandung akan arti adanya kejelasan dan kepastian mengenai :

a. Prosedur/tata cara pelayanan;

b. Persyaratan pelayanan, baik persyaratan teknis maupun persyaratan administratif;

c. Unit kerja dan atau pejabat yang berwenang dan bertanggung jawab dalam memberikan pelayanan;

d. Rincian biaya/tarif pelayanan dan tata cara pembayarannya;

e. Jadwal waktu penyelesaian pelayanan.

4. Keterbukaan, mengandung arti prosedur/ tata cara persyaratan, satuan kerja/pejabat penanggungjawab pemberi pelayanan, waktu penyelesaian, rincian waktu/ tarif serta hal-hal lain yang berkaitan dengan proses pelayanan wajib diinformasikan secara terbuka agar mudah diketahui dan dipahami oleh masyarakat, baik diminta maupun tidak diminta;

5. Efisiensi, mengandung arti :

a. Persyaratan pelayanan hanya dibatasi pada hal-hal berkaitan langsung dengan 
pencapaian sasaran pelayanan dengan tetap memperhatikan keter-paduan antara persyaratan dengan produk pelayanan yang berkaitan;

b. Dicegah adanya pengulangan pemenuhan persyaratan, dalam hal proses pelayanan masyarakat yang bersangkutan mempersyaratkan adanya kelengkapan persyaratan dari satuan kerja/ instansi pemerintah lain yang terkait.

6. Ketepatan waktu, kriteria ini mengandung arti pelaksanaan pelayanan masyarakat dapat diselesaikan dalam kurun waktu yang telah ditentukan;

7. Responsif, lebih mengarah pada daya tanggap dan cepat menanggapi apa yang menjadi masalah, kebutuhan dan aspirasi masyarakat yang dilayani;

8. Adaptif, cepat menyesuaikan terhadap apa yang menjadi tuntutan, keinginan dan aspirasi masyarakat yang dilayani yang senantiasa mengalami tumbuh kembang.

Dalam konteks pelayanan publik, dikemukakan bahwa pelayanan umum adalah mendahulukan kepentingan umum, mempermudah urusan publik, mempersingkat waktu pelaksanaan urusan publik dan memberikan kepuasan kepada publik (publik umum). Senada dengan itu, Moenir (1992) mengemukakan bahwa pelayanan publik adalah kegiatan yang dilakukan oleh seseorang atau sekelompok orang dengan landasan faktor material melalui sistem, prosedur dan metode tertentu dalam usaha memenuhi kepentingan orang lain sesuai dengan haknya. Dalam versi pemerintah, definisi pelayanan publik dikemukakan dalam UU No. 25 Tahun 2009 tentang Pelayanan Publik yaitu segala bentuk pelayanan yang dilaksanakan oleh instansi pemerintah di pusat, di daerah, dan di lingkungan Badan Usaha Milik Negara (BUMN) atau Badan Usaha Milik Daerah (BUMD) dalam bentuk barang dan atau jasa, baik dalam rangka upaya pemenuhan kebutuhan masyarakat maupun dalam rangka pelaksanaan ketentuan peraturan perundang-undangan.
Berdasarkan uraian diatas, dapat disimpulkan bahwa dalam menentukan kualitas pelayanan publik sangat dipengaruhi oleh faktor struktur organisasi, kemampuan aparat dan sistem pelayanan. Ketiga faktor ini saling berkaitan satu sama lain dan tidak dapat dipisahkan dalam ikut menentukan tinggi rendahnya dan baik buruknya suatu pelayanan yang diselenggarakan oleh pemerintah.

Kualitas pelayanan publik mempunyai indikator ketepatan waktu, kemudahan dalam pengajuan, akurasi pelayanan yang bebas dari kesalahan dan biaya pelayanan. Hal tersebut sangat dipengaruhi oleh faktor struktur organisasi, kemampuan aparat dan sistem pelayanan. Semakin baik faktor struktur organisasi, kemampuan aparat dan sistem pelayanan maka kualitas pelayanan publik akan semakin baik pula dan semakin dapat memuaskan masyarakat sebagai pengguna hasil pelayanan, dengan demikian. Sehingga kualitas pelayanan publik yang berkualitas dapat tercapai, akan hal tersebut kami paparkan dalam bentuk kerangka pikir peneltian berikut ini ;

Kerangka Pikir Penelitian

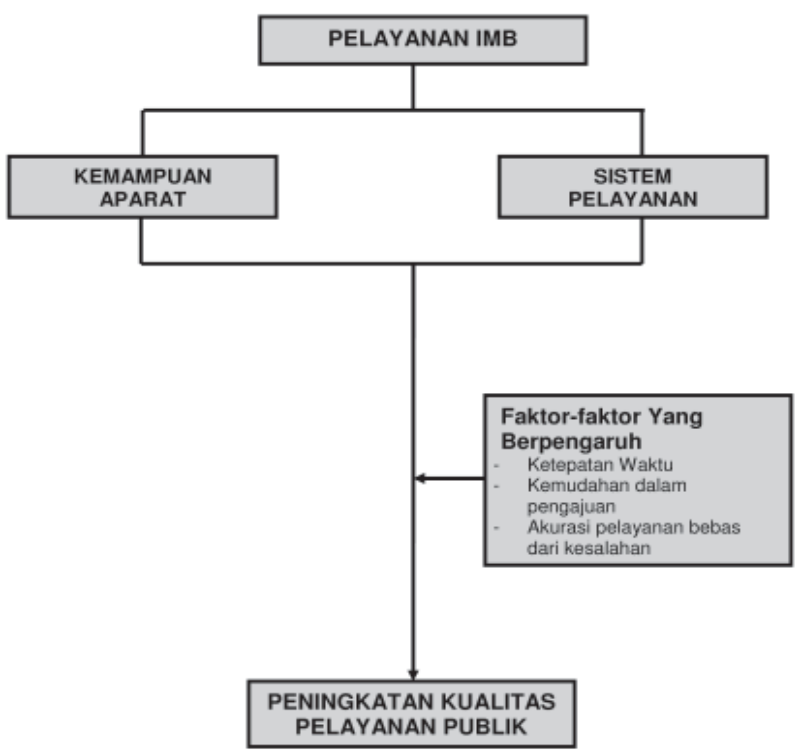

\section{E. METODE PENELITIAN}

Penelitian menggunakan metode pendekatan kualitatif dengan tujuan menggambarkan penyusunan program secara deskriptif kualitatif dengan pendekatan jenis penelitian asosiatif yang berupaya menafsirkan data 
yang berkenaan dengan fakta, keadaan, variabel dan fenomena yang terjadi saat penelitian berlangsung.

Pemilihan informan dilakukan secara purposive, artinya teknik penentuan informan dipilih secara sengaja dengan pertimbangan bahwa informan tersebut dianggap mampu memberikan informasi atau data yang relevan dengan permasalahan penelitian. Informan penelitian ini adalah pegawai pada kantor pelayanan satu atap. Teknik pengumpulan data dilakukan dengan cara pengamatan secara intensif (observation), wawancara yang dilakukan secara mendalam (in depth interview) dan teknik dokumentasi serta telaah kepustakaan.

\section{F. HASIL PENELITIAN DAN PEMBAHASAN}

Pelayanan publik yang diberikan oleh aparat pemerintah dalam suatu birokrasi pemerintahan sudah menjadi rahasia umum bahwa kualitasnya rendah. Namun hal ini tidak menjadikan alasan utama untuk tetap pesimistik atas perubahan yang mungkin terjadi dalam paradigma pelayanan yang selama ini menempatkan aparat dengan birokrasinya pada posisi yang harus dilayani, tetapi harus berubah kepada paradigma yang menempatkan pengguna jasa (konsumen) pada posisi yang lebih tinggi. Pelaksanaan pelayanan publik khususnya pelayanan Izin Mendirikan Bangunan (IMB) di Kabupaten Bone.

Pemerintah Kabupaten Bone telah melimpahkan kewenangan tersebut kepada Pemerintah Kantor Pelayanan Terpadu Satu Atap di Kabupaten Bone. Adapun peraturan yang mendasari pelaksanaan kewenangan pelayanan IMB di Kantor Pelayanan Terpadu Satu Atap di Kabupaten Bone adalah sebagai berikut :

1) Undang-undang Republik Indonesia (Nomor 28Tahun 2002) Tentang Bangunan Gedung.

2) Peraturan Pemerintah Republik Indonesia (Nomor 45 Tahun 1998) Tentang Perubahan Atas Peraturan Pemerintah Nomor 20 Tahun 1997 tentang retribusi Daerah.
3) Keputusan Bupati Bone (Nomor 15 Tahun 2008) Tentang Penunjukkan Kantor Pelayanan Terpadu Satu Atap di Kabupaten Bone Sebagai Tempat Pelayanan Permohonan Izin Mendirikan Bangunan (IMB), Izin Penggunaan Bangunan (IPB) dan Izin Perpanjangan Penggunaan Bangunan (IPPB) Khusus Rumah Tinggal.

Permohonan surat Izin Mendirikan Bangunan (IMB) dapat dilakukan oleh perorangan, kelompok, badan hukum atau instansi pemerintah maupun swasta. Izin Mendirikan Bangunan (IMB) diperlukan semata-mata bertujuan agar adanya tertib bangunan. Berbagai faktor yang mempengaruhi sistem pelayanan publik, khususnya dalam pelayanan Izin Mendirikan Bangunan (IMB) pada kantor pelayanan terpadu satu atap yakni (a), struktur organisasi, (b), kemampuan aparat (c), sistem pelayanan. Keinginan untuk mewujudkan pemerintahan yang baik merupakan idaman dari masyarakat, keinginan tersebut berangkat dari suatu asumsi dasar tentang pembentukan pemerintahan itu sendiri, yaitu untuk memberikan kesejahteraan kepada masyarakatnya melalui pelayanan yang diberikan, bahwa hal ini hanya dapat diwujudkan jika pengelolaan pemerintahan dilakukan oleh organisasi pemerintahan yang benar-benar konsisten terhadap masyarakat dan bangsanya.

\section{Kemampuan Aparat}

Pembahasan mengenai kemampuan aparat ini, akan diawali dari konsep bahwa kemampuan aparat dalam penelitian ini adalah suatu keadaan yang menunjukkan pengetahuan, kemampuan dan kemauan dari aparat untuk melaksanakan tugas dalam rangka memperlancar tujuan organisasi. Kemampuan sumber daya manusia (aparat) pada suatu lembaga sangat menentukan perkembangan lembaga tersebut. Kemampuan aparat secara formal dapat dilihat dari tingkat pendidikannya, kemampuan penyelesaian pekerjaan sesuai jadwal, namun dalam proses pelaksanaan pelayanan sesuai tugas pokok dan fungsinya diatur dalam struktur organisasi. 
2. Struktur Organisasi

Dalam hal restrukturisasi dan reorganisasi Kantor Pelayanan Terpadu Satu Atap (KPTSA) Kabupaten Bone telah lama muncul ide untuk dilakukan, seperti yang terungkap dari hasil wawancara yang dikemukakan Bapak AS sebagai berikut :

"Baiknya untuk Kantor Pelayanan Terpadu Satu Atap (KPTSA) Kabupaten Bone biar tetap eksis dibuat struktur organisasi sendiri, sehingga adanya eselon bagi Kepala Kantor Pelayanan Terpadu Satu Atap (KPTSA) Kabupaten Bone nantinya. Jadi semua kegiatan pelayanan terpusat di satu tempat, dan instansi yang terkait menempatkan personilnya di Kantor Pelayanan Terpadu Satu Atap (KPTSA) itu. Ini tentu akan lebih efisien dan efektif "

(Wawancara, 7 Mei 2011).

Berdasarkan dari apa yang dikemukakan oleh salah seorang informan maka dapat dianalisa bahwa dengan keberadaan Kantor Pelayanan Terpadu Satu Atap (KPTSA) Kabupaten Bone dalam hal struktur organisasi dari segi tingkat pembagian tugas pokok dan fungsi sudah terlihat adanya pembagian tugas pokok dan fungsi yang jelas. Karena dalam pelaksanaan sehari-hari petugas yang bertugas di Kantor Pelayanan Terpadu Satu Atap (KPTSA) Kabupaten Bone hanya berjumlah 10 (sepuluh) orang, yang terdiri dari : 1 orang petugas Tata Usaha (TU); 8 orang petugas loket pelayanan; 1 orang petugas bagian umum pengamatan penulis bahwa dari 10 (sepuluh) orang yang bertugas ini, kelemahan yang terlihat adalah hanya beberapa petugas yang berstatus sebagai Pegawai Negeri Sipil (PNS), sedangkan yang lainnya pegawai yang berstatus Rollsstaads atau yang lebih dikenal dengan pegawai honorer.

3. Sistem Pelayanan.

Tugas pokok dan fungsi yang diatur dalam pelaksanaan pelayanan publik, khususnya pada izin mendirikan bangunan (IMB) terlaksana dengan baik, demikian pula dengan pelaksanaan tugas antar instansi juga terlaksana dengan baik, walaupun dengan waktu yang kurang efisien dikarenakan setiap urusan pelayanan baru akan diproses setelah terku-mpul beberapa formulir pengajuan dan baru dibawa ke instansi terkait. Hal ini diungkapkan oleh Bapak YA sebagai berikut:

"Pengurusan IMB dilakukan bilamana, kalau yang mengurus IMB dalam satu hari sudah terkumpul banyak baru dibawa ke Bagian perizinan untuk diproses. Sedangkan kalau masih sedikit menunggu dulu yang mengurus besoknya baru diproses".

(Wawancara 15 Mei, 2011).

Berdasarkan pengamatan penulis bahwa dalam hal pelayanan publik yang dilakukan pada Kantor pelayanan terpadu satu atap, nampak terjadi sistem pelayanan berdasarkan tingkat hubungan antara atasan dan bawahan, disisi lain masih terlihat adanya budaya bugis yang sangat mempengaruhi dalam hubungan bapak dengan anak. Hal ini disebut budaya paternalisme yang memandang atasan sebagai pihak yang harus dihormati oleh bawahannya, selain itu bawahan hanya dipandang sebagai alat untuk menjalankan perintah atasannya, sehingga ada kecenderungan bahwa aparat birokrasi yang telah menjadi pimpinan mempertahankan kedudukannya karena dirasakan mampu memberikan keuntungan finansial dan sosial.

Dari hasil penelitian diperoleh bahwa kemampuan aparat yang semakin tinggi dan semakin baik maka akan berpengaruh terhadap kualitas pelayanan yaitu akan semakin baik.Tetapi dalam kasus di Kabupaten Bone ini dalam hal kemampuan aparat, indikator pendidikan aparat ternyata tidak sesuai dengan konsep yang ada. Dimana dalam konsep yang ada semakin tinggi pendidikan aparat maka kemampuannnya semakin baik, tetapi kasus di Kabupaten Bone tingkat pendidikan aparat tidak membawa pengaruh yang significant terhadap kemampuan 
aparat dalam hal kualitas pelayanan. Indikator lain dalam variabel kemampuan aparat adalah kemampuan penyelesaian pekerjaan sesuai jadwal, dengan maksud bahwa prosedur yang dilakukan oleh pengguna jasa tidak memerlukan waktu yang ditunda-tunda dalam melaksanakan pelayanan terhadap masyarakat. Permasalahan kemampuan aparat dalam melakukan kerja sama di Kantor Pelayanan Terpadu Satu Atap (KPTSA) Kabupaten Bone, terlihat masih menjadi kendala demikian pula halnya kerja sama antara atasan dan bawahan kurang tercipta dengan baik, bawahan hanya meminta petunjuk atasan kalau merasa bingung dalam memutuskan sesuatu kebijakan yang akan dilakukan, hal ini sebagaimana yang diungkapkan oleh Bapak $R A$ sebagai berikut:

"Sebagai pegawai apabila ada pekerjaan yang tidak pas, maka harus minta petunjuk atasan soalnya sebagai bawahan harus loyal. Loyalitas itu wajar-wajar saja, supaya setiap tindakan yang kita ambil itu benar. Jadi, kebijakan tetap ada di tangan atasan"

(Wawancara 15 Mei, 2010).

Sebagai institusi yang bertugas melayani publik dalam hal ini masyarakat, Kantor Pelayanan Terpadu Satu Atap (KPTSA) Kabupaten Bone yang diwakili oleh Kepala Kantor secara periodik memberikan pertanggungjawaban kepada bapak Bupati Bone. Hal-hal yang dilaporkan adalah mengenai laporan keuangan hasil pemasukan dari Kantor Pelayanan Terpadu Satu Atap (KPTSA) Kabupaten Bone. Hal Ini penting sekali karena laporan keuangan tersebut akan dipertanggungjawabkan kepada masyarakat dalam bentuk pembangunan melalui Pendapatan Asli Daerah (PAD).

4. Kenyamanan dalam memperoleh pelayanan

Kenyataan yang ada di Kantor Pelayanan Terpadu Satu Atap (KPTSA) Kabupaten Bone menunjukkan bahwa faktor kenya- manan bagi masyarakat kurang diperhatikan. Hal ini terlihat dari kondisi ruang pelayanan yang tidak memperhatikan faktor kenyamanan berdasarkan stándar.

5. Kejelasan informasi

Selain hal tersebut diatas, dalam mendukung sistem pelayanan, pihak Kantor Pelayanan Terpadu Satu Atap (KPTSA) Kabupaten Bone juga memberikan kejelasan informasi tentang pelayanan yang diberikan berkaitan dengan pelayanan publik yang diberikan. Hal tersebut dilakukan sebagai upaya dalam rangka menjalin hubungan dengan masyarakat sebagai pihak yang harus dilayani dengan baik. Apabila ada keluhan dari masyarakat yang berkaitan dengan pelayanan publik, masyarakat dapat mengadukan keluhan tersebut melalui media massa Radar Bone (milik Pemda Kabupaten Bone) atau melalui radio Suwara Daya Indah. Berkaitan dengan perlindungan terhadap dampak hasil pelayanan, Kantor Pelayanan Terpadu Satu Atap (KPTSA) Kabupaten Bone seperti yang telah dijelaskan sebelumnya bahwa pihak Kantor Pelayanan Terpadu Satu Atap (KPTSA) Kabupaten Bone menjamin dan memberikan perlindungan terhadap konsumen apabila ada kesalahan.

\section{G. FAKTOR-FAKTOR YANG MEMPENGARUHI KUALITAS PELAYANAN}

Salah satu indikator dalam memperoleh kualitas pelayanan publik yang baik maka yang perlu untuk diperhatikan adalah ketepatan waktu pelayanan yang berkaitan dengan waktu tunggu dan proses. Semakin cepat dan tepat waktu dalam proses pelayanan, maka akan membuat pengguna jasa semakin puas, selain itu kemudahan dalam pengajuan permohonan dan kelengkapan administrasi yang menyangkut prosedur atau tata cara, tidak berbelit-belit, mudah dipahami dan dilaksanakan.

Sementara itu, indikator berikutnya akurasi pelayanan yang berkaitan dengan apakah pelayanan tersebut bebas dari kesalahan, 
menunjukkan dalam setiap permohonan pelayanan masih diketemukan kesalahankesalahan yang berkaitan dengan hal-hal teknis, misalnya kesalahan dalam proses mencetak dokumen. Hal ini patut sebenarnya masih dapat dianggap wajar, tetapi sebagai konsumen yang ingin mendapat pelayanan yang terbaik seharusnya setiap kesalahan hendaknya dapat dikurangi bahkan tidak terdapat kesalahan sedikitpun.

Indikator terakhir dalam menentukan kualitas pelayanan publik di Kantor Pelayanan Terpadu Satu Atap (KPTSA) Kabupaten Bone yang dilakukan dalam penelitian ini merupakan indikator besarnya biaya pelayanan, faktor biaya pelayanan dianggap penting karena faktor ini paling rawan dan krusial sekali di mata banyak pihak. Penetapan besarnya biaya pelayanan telah ditetapkan dengan Peraturan Daerah Kabupaten Bone, karena sangat membantu dalam memperoleh Pendapatan Asli Daerah (PAD).

\section{H. KESIMPULAN DAN SARAN}

\section{Kesimpulan}

Kualitas pelayanan publik di Kantor Pelayanan Terpadu Satu Atap (KPTSA) Kabupaten Bone dapat dikatakan masih rendah, hal ini disebabkan antara lain; Masih tidak konsistennya antara waktu tunggu dengan waktu penyelesaian dalam memberikan pelayanan kepada masyarakat sebagai konsumen., Belum adanya sistem yang terkomputerisasi dan terintegrasi online dengan instansi terkait. Pelayanan kepada masyarakat dilayani dengan tanggap dan cepat, namun daya inisiatif dan kreativitas masih kurang, terlalu prosedural.

\section{Saran}

Perlunya peningkatan kualitas pelayanan publik terhadap pelayanan Izin Mendirikan Bangunan (IMB) maka di harapkan pendidikan dan pelatihan lebih ditingkatkan, demikian pula dengan ketepatan waktu melayani sehingga disarankan untuk melaksanakan pelayanan dengan sistem on line terhadap berbagai urusan pelayanan publik pada Kantor Pelayanan Terpadu Satu Atap kabupaten Bone. Dilihat dari kemampuan aparat, harus melaksanakan prinsip 'The right man in the right place' maka dalam pendelegasian tugas dan wewenang serta pemberian kesempatan kepada pegawai untuk memegang tanggung jawab perorangan harus jauh dari pola pendekatan hubungan pribadi, tetapi lebih ditekankan pada objektifitas kualitas keahlian dan kecakapan individu penerima wewenang.

\section{DAFTAR PUSTAKA}

Linquist, Evert, 2006, "Organizing for Policy Implementation: The Emergence and Role of Implementation Units in Policy Design and Oversight" Journal of Comparative Policy Analysis, Vol. 8, No. 4, December 2006 (pp.311-324) http:/ /www.tandfonline.com/page/termsandconditions, diakses (09 Agustus 2011)

Moenir, H.A.S., 1992, Manajemen Pelayanan Umum di Indonesia, Bumi Aksara, Jakarta.

Osborne, David dan P. Plastrik, 1997, Banishing Bureaucracy : The Five Strategies for Reinventing Government, New York, Addison-Wesley.

Supranto, 2001, Pengukuran Tingkat Kepuasan: Untuk Menaikkan Pangsa Pasar, Rineka Cipta, Jakarta.

Tobirin, 2008, "Penerapan Etika Moralitas Dan Budaya Malu Dalam Mewujudkan Kinerja PNS Yang Profesional" Civil Service: Jurnal Kebijakan \& Manajemen PNS, Vol.II No. 2 (2008) (Hal. 53-79)

Widodo, Joko, 2001, Good Governance : Telaah dari Dimensi Akuntabilitas dan Kontrol Birokrasi Pada Era Desentralisasi dan Otonomi Daerah, Insan Cendekia, Surabaya.

Zeithaml, Valarie A., (et.al), 1990, Delivering Quality Services: Balancing Customer Perceptions and Expectations, The Free Press, A Division of Macmillan Inc., New York. 


\section{DOKUMEN PUBLIK}

Undang-Undang No. 25 Tahun 2009 Tentang Pelayanan Publik

Peraturan Bupati Bone N0. 74 tahun 2008 Tentang Rincian tugas, fungsi dan tata kerja kepala unit, sekertaris, kepala bagian tata usaha, kepala bidang dan sub bagian pada unit pelayanan terpadu perizinan Kabupaten Bone.
Peraturan Daerah Kabupaten Bone N0. 25 Tahun 2009 Tentang Izin Mendirikan Bangunan

Keputusan Bupati Bone (Nomor 15 Tahun 2008) Tentang Penunjukkan Kantor Pelayanan Terpadu Satu Atap di Kabupaten Bone Sebagai Tempat Papelayanan Permohonan Izin Mendirikan Bangunan (IMB), Izin Penggunaan Bangunan (IPB) dan Izin Perpanjangan Penggunaan Bangunan (IPPB) Khusus Rumah Tinggal. 